\title{
Growth and the development of dietary obesity in adulthood of rats which have been undernourished during development
}

\author{
BY D. N. STEPHENS \\ University of Manchester, \\ The Department of Child Health, Stopford Building, \\ Oxford Road, Manchester Mi3 9PT
}

(Received 28 January $1980-$ Accepted 29 April 1980)

1. The effect of feeding a highly-palatable and varied diet on growth and body composition was assessed in male rats, some of which had undergone a period of undernutrition early in their development.

2. Undernutrition during gestation had no effects on weight, length or fat content of offspring in adulthood. Rats underfed during the first 3 weeks of postnatal life were shorter, lighter and more lean as adults than controls which had been well nourished through life.

3. Feeding the palatable diet from weaning led to increases in length and fat-free mass, and to comparable extents of obesity in all groups, irrespective of whether they had suffered either period of undernutrition. Access to palatable food for $30 \mathrm{~d}$ in adulthood also led to obesity, but to increases in length and fat-free mass in only the groups undernourished during suckling.

4. Withdrawal of the palatable diet led to some initial weight loss in all groups, irrespective of whether they had been undernourished during development; and $100 \mathrm{~d}$ following the replacement of the palatable with stock diet, there were no longer differences in weight between groups which had received palatable food, and those given stock diet throughout.

5. Nevertheless, those rats which had been undernourished during the suckling period and subsequently fed on the palatable diet still showed increased length and fat-free mass relative to their controls fed on the stock diet throughout.

6. All groups which had received the palatable diet, whether from weaning or as adults, and irrespective of early nutrition, were significantly less fat $100 \mathrm{~d}$ after its withdrawal than were those rats fed on the stock diet throughout life.

It is well established that a period of undernutrition during the suckling period slows growth in rat pups, and that such a temporary restriction in the nutrient supply permanently alters the rat's capacity for growth, even when adequate food is subsequently made available (Widdowson \& McCance, 1960, 1963; Chow \& Lee, 1964; Dobbing \& Sands, I97I; Adlard et al. 1973; Williams et al. 1974). A number of factors have been suggested as contributing to this stunting (Dobbing, 1980; Sands et al. 1979) including a setting downwards of hypothalamic mechanisms controlling food intake (Widdowson, 1971; Widdowson \& McCance, 1975; Cheng et al. 1971). Certainly, an altered responsiveness to food is a commonly-reported effect of early-life undernutrition (Bronfenbrenner, I968; Smart et al. 1973; Crnic, 1979), but almost without exception, these findings can be interpreted that rats undernourished during the suckling period have a higher food motivation than controls. Why, then, do these rats fail to overeat sufficiently to allow 'catch-up' growth in terms of body-weight, of fat-free mass, or even body fat?

One possibility is that with normal laboratory diet, some factor such as non-nutritive bulk prevents further food intake, before the animal's energy or protein needs have been satisfied. Pitts \& Bull (1977) have demonstrated that feeding a high-fat diet to hitherto normally-nourished rats, and hence inducing increased energy intake, was effective in producing a larger fat-free body mass, as well as the expected increase in adiposity, provided the high-fat diet was supplied sufficiently early in life. This observation is consistent with the idea that energy intake is a limiting factor in growth, even in animals fed ad lib. a good-quality diet, and raises the possibility that increasing the energy supply of rats 
Table I. Summary of early nutritional and dietary treatments of rats at the various ages

\begin{tabular}{|c|c|c|c|c|c|c|c|}
\hline Age (d) $\ldots$ & $\begin{array}{l}\text { Conception } \\
\text { to birth }\end{array}$ & Birth-30 & & $30-100$ & $100-130$ & $130-230$ & \\
\hline $\begin{array}{l}\text { Period post } \\
\text { weaning (d) }\end{array}$ & $\ldots$ & - & Group & $0-70$ & $70-100$ & $100-200$ & $\begin{array}{l}\text { Dietary } \\
\text { group }\end{array}$ \\
\hline \multirow[t]{3}{*}{ Treatment } & $\begin{array}{l}\text { Mother fed } \\
\text { ad lib. }\end{array}$ & $\begin{array}{l}\text { Mother fed } \\
\text { ad lib. }\end{array}$ & $\mathbf{G}^{+} \mathbf{L}^{+}$ & $\begin{array}{c}\text { Stock diet } \\
\text { Stock diet } \\
\text { Palatable } \\
\text { diet }\end{array}$ & $\left.\begin{array}{c}\text { Stock diet } \\
\text { Palatable } \\
\text { diet } \\
\text { Palatable } \\
\text { diet }\end{array}\right\}$ & $\begin{array}{c}\text { Stock } \\
\text { diet }\end{array}$ & $\begin{array}{l}\mathbf{C}_{30} \\
\text { Pioo }\end{array}$ \\
\hline & $\begin{array}{l}\text { Mother fed } \\
\text { ad lib. }\end{array}$ & $\begin{array}{l}\text { Mother } \\
\text { under- } \\
\text { nourished }\end{array}$ & $\mathrm{G}^{+} \mathrm{L}^{-}$ & $\begin{array}{c}\text { Stock diet } \\
\text { Stock diet } \\
\text { Palatable } \\
\text { diet }\end{array}$ & $\left.\begin{array}{c}\text { Stock diet } \\
\text { Palatable } \\
\text { diet } \\
\text { Palatable } \\
\text { diet }\end{array}\right\}$ & $\begin{array}{l}\text { Stock } \\
\text { diet }\end{array}$ & $\begin{array}{l}\mathrm{C} \\
\mathrm{P}_{30} \\
\text { P100 }\end{array}$ \\
\hline & $\begin{array}{l}\text { Mother } \\
\text { under- } \\
\text { nourished }\end{array}$ & $\begin{array}{l}\text { Mother fed } \\
\text { ad lib. }\end{array}$ & $\mathbf{G}^{-} \mathbf{L}^{+}$ & $\begin{array}{l}\text { Stock diet } \\
\text { Palatable } \\
\text { diet }\end{array}$ & $\begin{array}{c}\text { Stock diet } \\
\text { Palatable } \\
\text { diet } \\
\text { Palatable } \\
\text { diet }\end{array}$ & $\begin{array}{l}\text { Stock } \\
\text { diet }\end{array}$ & $\begin{array}{l}\text { C } \\
\text { P30 } \\
\text { P100 }\end{array}$ \\
\hline
\end{tabular}

C, group fed stock diet; PIOO, group fed palatable diet for $100 \mathrm{~d}$; $\mathrm{G}^{+}$, mother well nourished during gestation; $\mathrm{L}^{+}$, mother well nourished during lactation; $\mathrm{G}^{-}$, mother undernourished during gestation; $\mathrm{L}^{-}$, mother undernourished during lactation.

which had been undernourished during their suckling period might allow them to show 'catch-up' growth relative to controls.

Since it has been reported recently that feeding a highly-palatable diet of 'supermarket foods' results in better weight gain than that induced by high-fat diets (Sclafani \& Springer, 1976), this means of inducing hyperphagia has been preferred. Further, since some reports suggest that rats undernourished during gestation also eventually diverge from controls in their growth rates (Chow \& Stephan, 1971; Whatson \& Smart, 1978), the present study included an investigation of rats undernourished at this time. Finally, since relatively little information is available on the effects of withdrawing a palatable diet from dietarilyobese animals, this was also studied in previously-undernourished as well as control rats.

\section{ANIMALS AND METHODS}

Animals. The day of mating was determined for thirty-three virgin female Lister hooded rats by examining vaginal smears for the presence of sperm. One-third of the pregnant females was allocated to an 'undernourished' group which were fed from the day of mating with a daily ration of good-quality food (Porton Mouse Diet, PMD; RHM Labsure Ltd, England) equal to half the amount eaten by ad lib.-fed pregnant controls. At birth, litters were removed from the mother and culled to eight rats per litter, consisting, where possible, of six males and two females. Half the litters from the ad lib.-fed mothers were cross-fostered to the undernourished mothers, who continued to receive a food ration equal to half that eaten by nursing controls. This procedure provided a group of pups which had been well nourished during gestation $\left(\mathrm{G}^{+}\right)$, but which were undernourished during suckling $\left(\mathrm{L}^{-}\right)$, the $\mathrm{G}^{+} \mathrm{L}^{-}$group. A G $\mathrm{G}^{-} \mathrm{L}^{+}$group was obtained by cross-fostering the litters from the undernourished mothers to well-fed mothers at birth. A final $\mathrm{G}^{+} \mathrm{L}^{+}$ 
group was obtained by cross-fostering amongst well-fed mothers. These treatments are summarized in Table $I$.

At 2 I d after parturition, all mothers were given free access to the PMD diet, and pups were separated from their mothers at $30 \mathrm{~d}$ of age. At this time, up to three male pups were chosen at random from each litter, and allocated to one of three dietary groups, as shown in Table I, such that no litter provided more than one pup to each group. Control rats (group C) were housed in groups of three or four per cage $(400 \times 250 \times 200 \mathrm{~mm})$ and fed PMD ad lib. A second dietary group was housed singly and given a high-palatability (P) diet by presenting them with an assortment of foods purchased from supermarkets, in addition to PMD. 'Supermarket foods' included various pasti, canned dog and cat foods, cakes, marshmallow, banana, baked beans, breakfast cereals, cheese, sausage, pulses, chocolate and biscuits. Three such foods were presented daily, and no individual supermarket food was presented more than once per week. This palatable $(P)$ diet continued for $100 \mathrm{~d}$ (dietary group Proo). Dietary group $\mathrm{P}_{30}$ was housed in groups of three or four and received PMD diet ad lib. from weaning; $70 \mathrm{~d}$ from weaning, i.e. at $100 \mathrm{~d}$ of age, they were rehoused singly, and were additionally provided with the palatable diet for $30 \mathrm{~d}$. At I $00 \mathrm{~d}$ from weaning, i.e. at $130 \mathrm{~d}$ of age, all groups were returned to the PMD diet alone, until the experiment ended $200 \mathrm{~d}$ from weaning.

Animal rooms were maintained at a temperature of $23^{\circ}$ and a relative humidity of $35 \%$, and on a $12 \mathrm{~h}$ red- $12 \mathrm{~h}$ white light cycle, the red phase beginning at 12.00 hours.

Body composition determination. The rats were weighed at $\mathrm{Io} d$ intervals and, in addition, at 100 , 130 and $230^{\circ} \mathrm{d}$ of age, body water was estimated by a tritium dilution method (Rothwell \& Stock, 1979a), and fat-free mass and body fat calculated using constants determined in our laboratory for previously-undernourished and control rats of our laboratory strain at the appropriate ages. Since the biological half life of tritium hydroxide is approximately $\mathrm{I} 4 \mathrm{~d}$, it is inevitable that significant amounts of THO from the $100 \mathrm{~d}$ estimation were still present in the rats at the time of the second body water estimation at $130 \mathrm{~d}$. This would have the effect of giving an underestimation of ${ }^{3} \mathrm{H}$ dilution at $130 \mathrm{~d}$ and hence an underestimate of body water content. No attempt has been made to correct for this but it is consequently inappropriate to compare values of body water and hence fat-free mass and body fat at the different ages. Rats were injected intraperitoneally with $10 \mu \mathrm{Ci}^{3} \mathrm{H}$ as THO in physiological saline ( $9 \mathrm{~g}$ sodium chloride/1). After $2-3 \mathrm{~h}$, they were lightly anaesthetized with diethyl ether, and a blood sample taken from the orbital sinus into heparinized tubes. Plasma samples ( $0.1 \mathrm{ml}$; triplicates) were taken and ${ }^{3} \mathrm{H}$ content estimated by liquid-scintillation in either a Nuclear Chicago (at ages 100 and $130 \mathrm{~d}$ ) or a Tracerlab Spectromatic (on day 230) counter, using PCS (Hopkin and Williams, Manchester, England) as scintillant. A sample of the injected dose of ${ }^{3} \mathrm{H}$ was also counted in triplicate, and body water calculated from the activity ratio, dose:plasma water. Fat-free mass was calculated from the body water content using a value determined in our laboratory of $748 \mathrm{~g} / \mathrm{kg}$ for the water content of fat-free carcass, and body fat calculated by subtracting fat-free mass from the rat's body-weight. The value of $748 \pm 8 \mathrm{~g} / \mathrm{kg}$ was not appreciably different from the $732 \mathrm{~g} / \mathrm{kg}$ reported by Pace \& Rathbun (1945) for water content of fat-free carcass.

Values for body water obtained in a separate series of eighteen rats by the ${ }^{3} \mathrm{H}$ dilution method were compared with values from the same animals obtained by desiccation of minced samples of carcass (including gut). ${ }^{3} \mathrm{H}$ estimated values did not differ significantly from those obtained by desiccation (paired $t 0.05 \mathrm{I}$; not significant), and were highly correlated $(r 0.995$, df $16, P<0.001)$.

Comparison of values for body fat calculated from ${ }^{3} \mathrm{H}$-estimated body water with values obtained by chloroform-methanol extraction of fresh carcass samples showed that ${ }^{3} \mathrm{H}$ estimated values were significantly lower than those obtained by extraction (paired $t$ 9.924, 
Table 2. Body-weights ( $g$ ) of the three early nutritional groups of rats at three ages $\dagger$

(Mean values with their standard errors)

\begin{tabular}{|c|c|c|c|c|c|c|}
\hline \multirow[t]{2}{*}{ Age } & \multicolumn{2}{|c|}{ Birth } & \multicolumn{2}{|c|}{$21 \mathrm{~d}$} & \multicolumn{2}{|c|}{$30 \mathrm{~d}$} \\
\hline & Mean & $\mathbf{S E}$ & Mean & $\mathbf{S E}$ & Mean & SE \\
\hline $\begin{array}{l}\mathbf{G}^{+} \mathbf{L}^{+} \\
\mathbf{G}^{-} \mathbf{L}^{+} \\
\mathbf{G}^{+} \mathbf{L}^{-}\end{array}$ & $\begin{array}{l}5.5 \\
4.5 \\
5.8\end{array}$ & $\begin{array}{l}0.2 \\
0.2^{* * *} \\
0.2\end{array}$ & $\begin{array}{l}50.8 \\
42.2 \\
16.7\end{array}$ & $\begin{array}{l}3 \cdot 0 \\
2 \cdot 8^{*} \\
0 \cdot 4^{* * *}\end{array}$ & $\begin{array}{l}80 \cdot 5 \\
78 \cdot 4 \\
30 \cdot 3\end{array}$ & $\begin{array}{l}2 \cdot 6 \\
3 \cdot 2 \\
2 \cdot 0^{* * *}\end{array}$ \\
\hline
\end{tabular}

$\mathrm{G}^{+}$, mother well nourished during gestation; $\mathrm{L}^{+}$, mother well nourished during lactation; $\mathrm{G}^{-}$, mother undernourished during gestation; $\mathrm{L}^{-}$, , mother undernourished during lactation.

Value different from $\mathrm{G}^{+} \mathrm{L}^{+}$group; ${ }^{*} P<0.05,{ }^{* * *} P<0.001$.

$\dagger$ For details of treatments, see Table $\mathbf{I}$.

$P<0.001)$, but were highly correlated $(r 0.950$, df $16, P<0.001)$ with a linear relationship:

$$
y=0.966 x+9.45
$$

where $y$ is fat estimated by chloroform-methanol extraction, and $x$ is fat calculated from body water.

These relationships were also found to hold for a group of experimental rats killed at $230 \mathrm{~d}$ of age, and all values for body fat reported here have, therefore, been corrected using the previously mentioned equation.

Lastly, at the time of collection of blood samples for plasma ${ }^{3} \mathrm{H}$ estimates, naso-anal length was measured using a measuring platform similar to that described by Hughes \& Tanner (1970).

Statistical tests. Weight curve values for groups $\mathrm{C}$ and Pioo were compared by trend analysis using multivariate analysis of variance (UMRCC, 1978), with three factors, namely, age, timing of early undernutrition, and type of postweaning diet. Such analysis provides information as to whether the curves describing changes in weight with age are parallel, whether the weight changes with age, and whether the over-all mean values for weight, averaged across age, differ between groups.

Values for weight, length, fat-free mass, body fat content, and fat as a percentage of body-weight were compared amongst groups using two-way analysis of variance (ANOVA), and comparison of pairs of values by one-way ANOVA.

\section{RESULTS}

Table 2 shows that undernourishing mothers while they were gestating reduced the birth weight of their pups by $18 \%$, but that by $30 \mathrm{~d}$ of age, this weight deficit had been abolished. Undernourishing the mothers while they were nursing resulted in a $67 \%$ deficit in weight of their pups when food was made freely available at $2 \mathrm{I} \mathrm{d}$ of age, and this percentage deficit did not change appreciably by $30 \mathrm{~d}$.

$100 \mathrm{~d}$ access to the palatable diet

Body-weight. The effects of feeding the palatable diet from $30 \mathrm{~d}$ are summarized in Table 3 and Fig. I. Irrespective of early nutrition, rats in the PIoo groups increased their weight more rapidly than those in all groups $\mathrm{C}$. However, as Fig. I reveals, weight curves 
Table 3. Probabilities associated with differences in the body-weight growth curves of three groups of rats with different early nutritional histories fed on two different diets $\dagger$

Dietary group ...

Diet C

Source of variance ...

Growth curves diverge

Weights averaged over

30-I 30 d different

Growth curves

indistinguishable

Early nutritional grou

Source of variance ...

Growth curves diverge

Weights, averaged over

30-I $30 \mathrm{~d}$ different

Growth curves

indistinguishable

$\begin{array}{cc}\mathrm{G}^{+} \mathrm{L}^{+} v \cdot \mathrm{G}^{-\mathrm{L}^{+}} & \mathrm{G}^{+\mathrm{L}^{+}} \text {v. } \mathrm{G}^{+} \mathrm{L}^{-} \\ \mathrm{NS} & \begin{array}{l}P<0.01 \\ \mathrm{NS}\end{array} \\ + & P<0.00001 \\ + & -\end{array}$

$\mathbf{G}^{+} \mathbf{L}^{+}$

C v. Proo

$P<0.001$

$P<0.01$
$\mathbf{G}^{-} \mathbf{L}^{+}$

C v. Proo

$P<0.05$

$P<0.01$
Diet P100

$\begin{array}{cl}\mathrm{G}^{+} \mathrm{L}^{+} v \cdot \mathrm{G}^{-\mathrm{L}^{+}} & \mathrm{G}^{+} \mathrm{L}^{+} v . \mathrm{G}^{+} \mathrm{L}^{-} \\ \mathrm{NS} & P<0.001 \\ \mathrm{NS} & P<0.0000 \mathrm{I} \\ + & -\end{array}$

$\mathbf{G}^{+} \mathbf{L}^{-}$

Cv. Pioo

$P<0.05$

$P<0.05$

+ , Curves indistinguishable; - , curves distinguishable; C, group fed stock diet; Proo, group fed palatable diet for $100 \mathrm{~d} ; \mathrm{G}^{+}$, mother well nourished during gestation; $\mathrm{L}^{+}$, mother well nourished during lactation; $\mathrm{G}^{-}$, mother undernourished during gestation; $\mathrm{L}^{-}$, mother undernourished during lactation. NS, not significant.

$\dagger$ For details, see Table I.

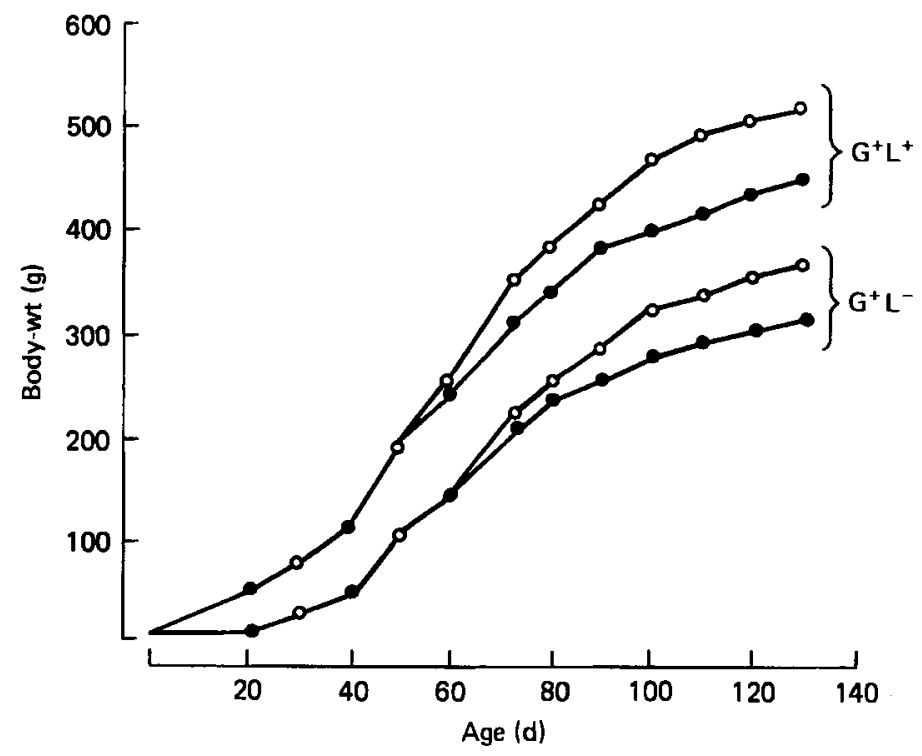

Fig. I. Body-weight (g) of four groups of rats from birth to $130 \mathrm{~d}$ of age. Groups $\mathbf{G}^{+} \mathbf{L}^{-}$were undernourished during the first 3 weeks of postnatal life; groups $\mathrm{G}^{+} \mathrm{L}^{+}$were well nourished throughout life; groups $\mathrm{G}^{-\mathrm{L}^{+}}$, undernourished as foetuses, are not shown since from $30 \mathrm{~d}$ onwards their growth curves were essentially coincident with groups $\mathrm{G}^{+} \mathbf{L}^{+}$fed the same diet. $\mathrm{O}-\mathrm{O}, \mathrm{PI} \infty \mathrm{diet} ; \mathrm{O}-\mathrm{C}$ diet; for details, see Table $\mathbf{1}$.

for the two diets did not diverge until approximately $60 \mathrm{~d}$ of age. Nevertheless, by I $30 \mathrm{~d}$, rats reared on the palatable diet weighed some 50-70 $\mathrm{g}$ more than those fed on PMD.

Analysis of the effect of the timing of early undernutrition indicated that there was no significant difference between the weight curves of groups $\mathrm{G}^{+} \mathrm{L}^{+}$and $\mathrm{G}^{-} \mathrm{L}^{+}$on either diet (Table 3). However, as Fig. I shows, group $\mathrm{G}^{+} \mathrm{L}-$ grew more slowly during the suckling period than did group $\mathrm{G}^{+} \mathbf{L}^{+}$, and continued to do so on both the palatable and the control 


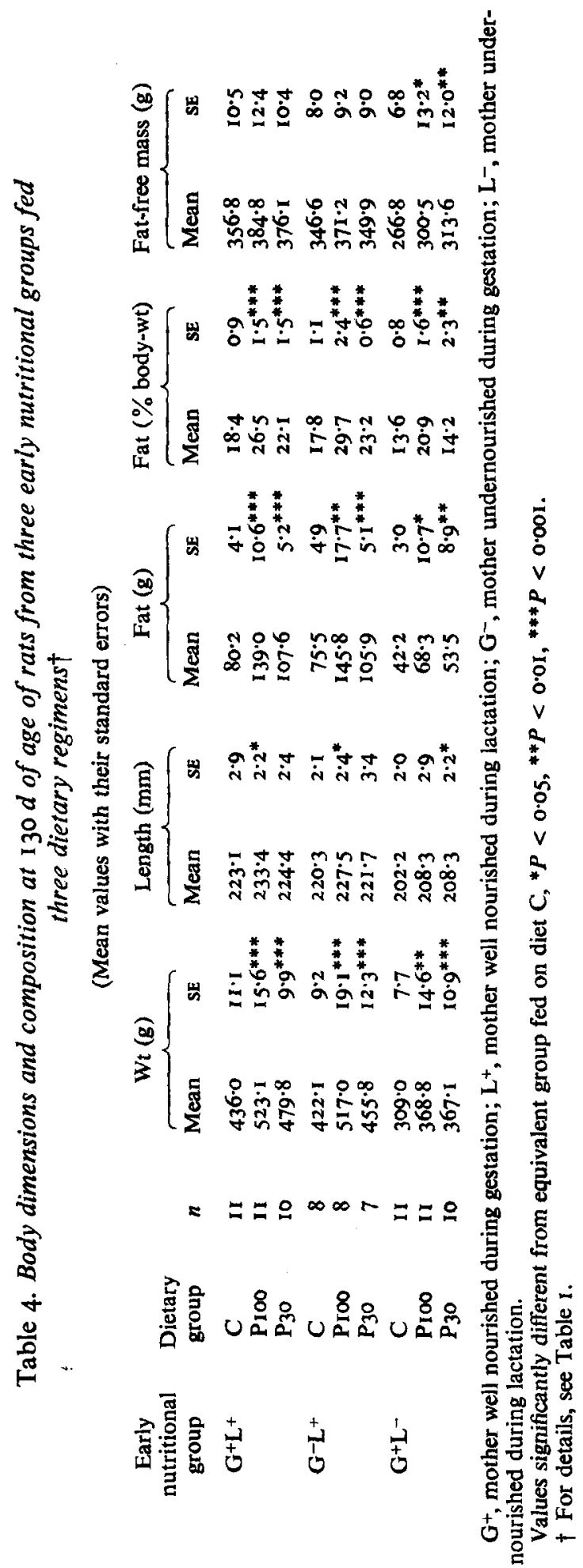


Table 5. Probabilities associated with differences in the specified variables after feeding rats from different early nutritional groups with either control $(C)$ or palatable $\left(P_{I} 00\right)$ diets $\dagger$ for Ioo $d$ from weaning

\begin{tabular}{|c|c|c|c|c|c|}
\hline \multirow{2}{*}{$\begin{array}{l}\text { Source of } \\
\text { variance }\end{array}$} & \multirow[b]{2}{*}{ Wt } & \multirow[b]{2}{*}{ Length } & \multicolumn{2}{|c|}{ Fat } & \multirow[b]{2}{*}{ Fat-free mass } \\
\hline & & & Total & $\%$ body-wt & \\
\hline $\begin{array}{l}\mathbf{G}^{+} \mathbf{L}^{+} v . \mathrm{G}^{-} \mathrm{L}^{+} \\
\text {C v. PIoo } \\
\text { Interaction }\end{array}$ & $\begin{array}{c}\text { NS } \\
P<0.001 \\
\text { NS }\end{array}$ & $\begin{array}{c}\text { NS } \\
P<0.001 \\
\text { NS }\end{array}$ & 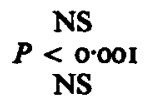 & $\begin{array}{c}\text { NS } \\
P<0 \cdot 001 \\
\text { NS }\end{array}$ & $\begin{array}{c}\text { NS } \\
P<0 \cdot 01 \\
\text { NS }\end{array}$ \\
\hline $\begin{array}{l}\mathbf{G}^{+} \mathbf{L}^{+} \boldsymbol{v} \cdot \mathbf{G}^{+} \mathbf{L}^{-} \\
\mathbf{C} v . \text { Proo } \\
\text { Interaction }\end{array}$ & $\begin{array}{c}P<0.001 \\
P<0.001 \\
\text { NS }\end{array}$ & $\begin{array}{c}P<0.001 \\
P<0.002 \\
\text { NS }\end{array}$ & $\begin{array}{l}P<0.001 \\
P<0.001 \\
P<0.05\end{array}$ & $\begin{array}{c}P<0.001 \\
P<0.001 \\
\text { NS }\end{array}$ & $\begin{array}{c}P<0.00 \mathrm{r} \\
P<0.01 \\
\text { NS }\end{array}$ \\
\hline
\end{tabular}

$\mathrm{G}^{+}$, mother well nourished during gestation; $\mathbf{L}^{+}$, mother well nourished during lactation; $\mathbf{G}^{-}$, mother undernourished during gestation; $L^{-}$, mother undernourished during lactation; NS, not significant.

$\dagger$ For details, see Table I.

diet (Table 3); and there was no evidence of 'catch-up' in terms of body-weight, even when comparing group $\mathrm{G}^{+} \mathrm{L}^{-}$given the palatable diet with group $\mathrm{G}^{+} \mathbf{L}^{+}$given the control diet.

In order to test whether the palatable diet induced similar weight gain in groups $\mathrm{G}^{+} \mathrm{L}^{+}$ and $\mathrm{G}^{+} \mathrm{L}^{-}$, a comparison was made between the two groups of the difference in weight between rats fed on the palatable diet, and their littermates fed on PMD. Trend analysis confirmed that the difference between weights of groups on the two diets increased with time (F (IO, II), I6.I2, $P<0.0001$ ); there was no significant difference, however, between groups $\mathrm{G}^{+} \mathrm{L}^{+}$and $\mathrm{G}^{+} \mathrm{L}^{-}$in either the mean value of the difference between the palatable and control diets, or in the way the difference changed over time.

A similar comparison on the same values transformed by expressing the difference in weight between littermates reared on the two diets as percentages of the weight of the littermates fed on the control diet, also failed to reveal any significant differences between the two groups.

Thus there was no evidence for a differential effect of the palatable diet on the weight curves of the various early nutritional groups.

Body composition at age $130 \mathrm{~d}$. Analysis of variance (ANOVA) of two factors (timing of early nutrition and type of postweaning diet) $100 \mathrm{~d}$ post weaning showed significant effects of both factors on body-weight, length, fat-free mass, fat, and fat as a percentage of body-weight. Further comparisons were, therefore, made between early nutritional groups $\mathrm{G}^{+} \mathrm{L}^{+}$, and $\mathrm{G}^{-} \mathrm{L}^{+}$, and between $\mathrm{G}^{+} \mathrm{L}^{+}$and $\mathrm{G}^{+} \mathrm{L}^{-}$.

$G^{+} L^{+}$v. $G^{+} L^{-}$. Rats undernourished during lactation were significantly lighter and shorter than well-nourished controls, had less fat-free mass, and less fat, both in absolute terms and as a percentage of body-weight (Table 4 ; for statistics, see Table 5). There was also a significant effect of diet, the PIoo groups being heavier, longer, fatter and with increased fat-free mass (Table 5). A significant interaction between dietary and early nutritional treatments (Table 5) suggests that the palatable diet induced a greater fat gain in group $\mathrm{G}^{+} \mathrm{L}^{+}$than in group $\mathrm{G}^{+} \mathrm{L}^{-}$; however, there was no significant interaction between diet and early nutritional history for fat expressed as a percentage of bodyweight.

$G^{+} L^{+}$v. $G^{-} L^{+}$. No effect of early nutritional history was found on weight, length, fatfree mass, fat, or fat as a percentage of weight (Table 4 ; for statistics, see Table 5). Similar effects of diet were found to those reported previously. 

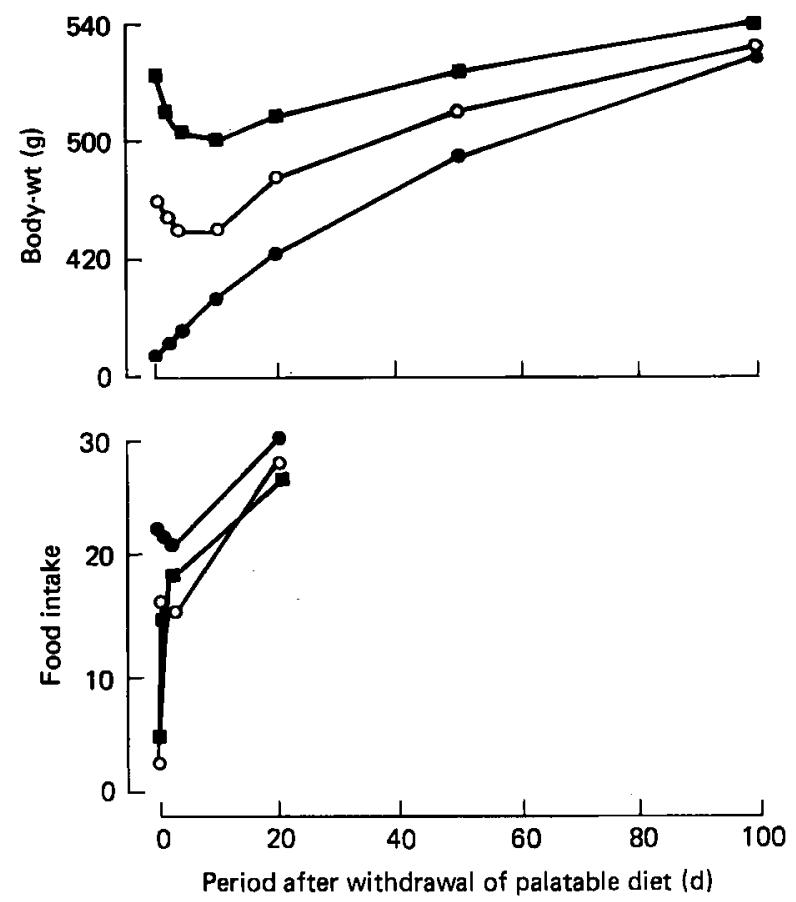

Fig. 2. Changes in body-weight $(g)$ and food intake $(g)$ in rats well nourished throughout life $\left(\mathrm{G}^{+} \mathrm{L}^{+}\right)$following withdrawal of the palatable diet. $\mathrm{O}$, Diet $\mathrm{C}$; $\mathrm{O}$, diet P30; $\mathbf{D}$, diet Pioo; dietary treatments between ages 30 and I $30 \mathrm{~d}$; for details, see Table I.

\section{Short-term access to the palatable diet}

Animals in the $\mathrm{P}_{30}$ group, which, therefore, had been treated exactly as animals given diet $C$ until roo d did not differ significantly from them at this time. Table 4 shows the effect of $30 \mathrm{~d}$ exposure to the palatable diet on body composition at $130 \mathrm{~d}$. As with long-term access to the palatable diet, short-term access led to increased weight and fat content. In contrast with the long-term access, feeding the palatable diet for $30 \mathrm{~d}$ did not result in significant increases in length and fat-free mass except in the lactationallyundernourished animals.

The effects of early-life undernutrition on body composition found in the groups given diets $\mathrm{C}$ and $\mathrm{P}_{100}$ were confirmed for the groups given diet $\mathrm{P}_{30}$, with group $\mathrm{G}^{+} \mathrm{L}^{-}$again significantly lighter, shorter and less fat than group $G^{+} L^{+}$given the same diet (Table 4 ). No differences emerged between groups $G^{-} L^{+}$and $G^{+} L^{+}$, and there were no significant interactions between early nutritional and dietary treatments.

\section{Withdrawal of the palatable diet}

When the palatable diet was withdrawn, both $\mathbf{P}$ groups lost weight for approximately Io d. Fig. 2 shows the body-weight changes for group $\mathrm{G}^{+} \mathrm{L}^{+}$, but both the other early nutritional groups behaved in a similar fashion. Food intake relative to groups given diet $\mathbf{C}$ throughout was significantly depressed for $2 \mathrm{~d}$ following removal of the palatable food, but thereafter returned to levels which were not significantly different from diet $\mathrm{C}$ controls.

In spite of similar energy intakes, by $100 \mathrm{~d}$ following withdrawal of the palatable diet, there was no longer a significant effect of dietary group on body-weight for any of the early nutritional groups (F $(2,77) \mathrm{I} \cdot 784$, not significant) and, although dietary group 


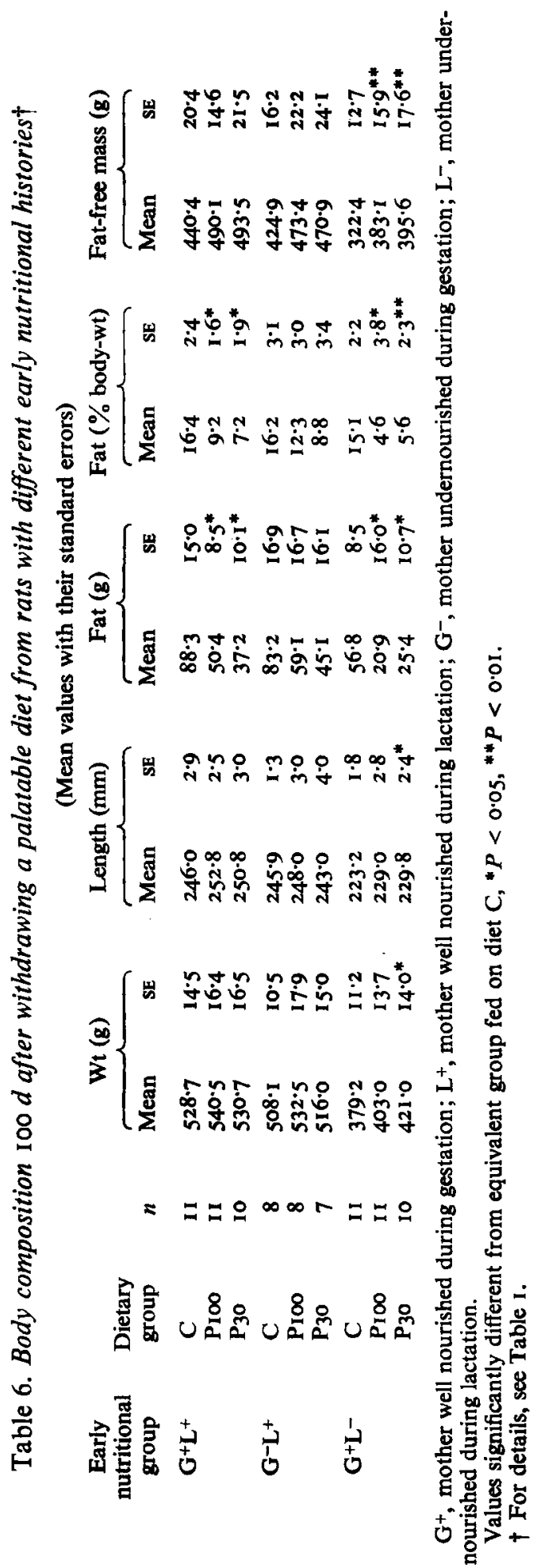


still had a significant effect on fat content, both in absolute amount $(\mathrm{F}(2,68) 3.413, P<0.05)$, and as a percentage of body-weight (F $(2,68) 4.167, P<0.02)$, the rats which had been given the palatable diet were now less fat than their littermates given diet $\mathrm{C}$ throughout. This tendency was observable in all three early nutritional groups (Table 6).

Apart from fat content, there were no other differences between groups fed on the palatable diet except in group $\mathrm{G}^{+} \mathrm{L}^{-}$where the increased length and fat-free mass noted at $\mathrm{I} 30 \mathrm{~d}$ of age persisted $100 \mathrm{~d}$ after withdrawal of the palatable diet. The increased length of rats fed on the palatable diet in groups $G^{+} L^{+}$and $G^{-} L^{+}$which was noted at $130 \mathrm{~d}$ was no longer present at $230 \mathrm{~d}$, suggesting that in these groups, the increase in naso-anal length may have been due to the accretion of fat around the base of the tail (Schemmel et al. I969).

\section{DISCUSSION}

It is now well established that feeding rats an ad lib. highly-palatable diet induces weight gain and obesity (Sclafani \& Springer, 1976; Sclafani \& Gorman, 1977; Rothwell \& Stock, I979 $b$; Rolls et al. 1980). The present experiment confirmed this finding and extended the general observation to rats which had undergone food deprivation during their early development. A complicating factor in the present experiment was the fact that the rats fed on the palatable diet were also housed singly, whereas those fed on the control diet were housed in groups of three or four. Mundy \& Porter (1969), however, report that increasing the number of rats in cages identical to ours from one to twelve per cage had no effect on body-weight, and in a separate experiment in this laboratory with both $\mathrm{G}^{+} \mathrm{L}^{+}$and $\mathrm{G}^{+} \mathrm{L}^{-}$rats housed in groups of either one or four and fed on PMD from weaning, no differences were found in length, weight or body composition of either previously undernourished or control rats housed under the two densities up to $230 \mathrm{~d}$ of age (D. N. Stephens, unpublished results). Nevertheless, it is possible that group housing might have facilitated feeding in the rats fed the palatable diet, leading to even greater obesity, but there is little reason to believe that group housing would have differential effects on previously undernourished and control rats in this respect.

Feeding the palatable diet for $100 \mathrm{~d}$ from weaning was more effective in inducing weight gain than was $30 \mathrm{~d}$ exposure to the diet in adulthood, even though, as previously reported for high-fat diets (Peckham et al. 1962; Schemmel et al. 1969) the palatable diet was ineffective in inducing weight gain until the rats were approximately 60 -d-old. A similar finding has been reported with rats given ventromedial hypothalamic lesions early in life (Kennedy, 1969; Bernardis, 1966), and in this instance the lack of weight gain until $60 \mathrm{~d}$ has been attributed to the young rats already eating at some ceiling level which could not be exceeded by brain damage (Kennedy, 1957). Such an explanation is unlikely to account for the failure of the palatable diet to induce weight gain in the first 2 months however, since Rothwell \& Stock (I980) find that weanling rats increase their energy intake by approximately $50 \%$ when fed on palatable food, though they do not show excessive weight gain.

Whatever the explanation, the same phenomenon was observed in all the early nutritional groups, and although there were differences between the lactationally-undernourished and control rats in their rates of weight gain, there was no evidence of 'catch-up' growth of the $\mathrm{G}^{+} \mathrm{L}^{-}$rats with their $\mathrm{G}^{+} \mathrm{L}^{+}$peers either before or after $60 \mathrm{~d}$ of age. The improvement in weight gain induced by the palatable diet did not differ amongst the early nutritional groups, and, further, $\mathrm{G}^{+} \mathrm{L}^{-}$rats fed on the palatable diet did not show 'catch-up' growth relative to the $\mathrm{G}^{+} \mathrm{L}^{+}$animals given even diet $\mathrm{C}$. From the evidence of body-weight, then, it seems unlikely that the persistently small size of the lactationally-undernourished rat can be attributed simply to their failure to eat enough. 
Body-weight, however, is a composite of several components and it is possible that by treating all these components as a single variable, more subtle effects are obscured. In the present experiment, no attempt has been made to go beyond a division of bodyweight into fat and fat-free tissue. Nevertheless, some evidence emerged that, with respect to fat-free mass, feeding the palatable diet did allow some small improvement in growth to occur in the lactationally-undernourished animals, although the improvement was not sufficient to constitute 'catch-up' in the sense of a converging trajectory. At $130 \mathrm{~d}$ of age, both the $\mathrm{G}^{+} \mathrm{L}^{-}$groups fed on the palatable diet showed increased fat-free mass, and increased naso-anal length. Similar findings also emerged for both the $\mathrm{G}^{+} \mathrm{L}^{+}$and $\mathrm{G}^{-} \mathrm{L}^{+}$ groups but, in contrast to the $\mathrm{G}^{+} \mathrm{L}^{-}$group, this improvement did not survive $100 \mathrm{~d}$ of feeding the control diet. In obese rats, the naso-anal length reflects not only skeletal length but also fat deposited around the base of the tail (Schemmel et al. 1969), and presumably this fact alone is sufficient to account for the increased lengths of both the $\mathrm{G}^{+} \mathrm{L}^{+}$and $\mathrm{G}^{-} \mathrm{L}^{+}$groups after $\mathrm{I00} \mathrm{d}$ of palatable diet. That the increased length of $\mathrm{G}^{+} \mathrm{L}^{-}$ rats fed on the palatable diet persisted after it was withdrawn suggests that in this instance, feeding the palatable diet from weaning induced a true increase in growth, albeit a small one. This increase in lean tissue occurred even when the palatable diet was fed only in adulthood. Examination of Tables 4 and 6, however, indicates that the rats were still increasing in length and in fat-free mass even between days 130 and 230 , showing that linear growth had not ceased at the time the palatable diet was fed. This finding is consistent with that of Hughes \& Tanner (1970), and may account for the ability of the palatable diet to enhance growth in the lactationally-undernourished animals, even at this late stage in development.

The same cannot be said about fat content, however. Although the present experiment replicated the well-documented finding that lactationally-undernourished rats are less fat than well-nourished controls, even after a period of refeeding (Widdowson \& McCance, 1960; Barnes et al. 1973; Smart et al. 1974), there was no evidence that the extent of obesity induced by feeding the palatable diet differed amongst the early nutritional groups, whether the palatable diet was fed from weaning, or only during adulthood. The fact that the $\mathrm{G}^{+} \mathrm{L}^{-}$animals were able to increase their fat content indicates that their leanness relative to controls when fed normal laboratory diet cannot be due to a reduced ability to synthesize or store fat.

The second aim of the present study was to provide information on the growth of rats undernourished during gestation. In contrast with both Chow \& Stephan (197I) and Whatson \& Smart (I978), the present study failed to demonstrate lasting effects of foetal undernutrition on body-weight or composition on any of the dietary regimens. The bodyweight deficit at birth in the present experiment was comparable to those achieved by those workers ( $18 v .20$ and $19 \%$ respectively), and considerably more than the I $2 \%$ deficit in the instance in the literature in which 'catch-up' was reported (Smart et al. 1973). However, the adult deficits in body-weight following foetal undernutrition reported by Chow \& Stephan (197I) and by Whatson \& Smart (1978) were not large and together with the present finding, are consistent with the existence of a vulnerable period at the time of suckling; undernutrition before, as well as after this time is less effective in permanently lowering the weight trajectory (Dobbing, 1980). It should be noted, however, that the body-weight deficit achieved by gestational undernutrition is always less than that achieved by undernutrition during the suckling period; less than half in the present experiment.

The last point which must be considered is the finding that $100 \mathrm{~d}$ following withdrawal of the palatable food, those groups which had become obese when fed on the palatable diet were now less fat than the rats fed on the control diet throughout life. This finding 
stands in contrast to a report that dietarily-obese rats remain fat after withdrawal of palatable foods (Rolls et al. 1980), but the fact that the increased leanness occurred in all three early nutritional groups in the present experiment, and occurred whether the palatable diet was fed from weaning or only during adulthood, emphasizes the reliability of the effect in our laboratory. The experiment reported here differed from that of Rolls et al. (I980) in a number of respects, including an increase in the variety of diet offered in the present study, and in the fact that our cages were considerably larger than theirs. Perhaps the opportunity to exercise, a factor which has been shown to be important in determining the effectiveness of palatable diets in inducing obesity (Rolls \& Rowe, I979), is also important in determining whether obese rats are able to lose weight.

The actual mechanism by which animals could lose so much fat following withdrawal of a palatable diet is not known, but it seems possible that the reduced food intake of the $\mathbf{P}$ groups, whilst not reaching significance, was a contributory factor to weight loss. Additionally, Rothwell \& Stock (1978) have reported that weight loss can sometimes occur despite a greater energy intake in dietarily-obese rats, and in this instance they find that the obese rats from which palatable food is withdrawn, lose fat by increasing resting energy expenditure. Although their findings refer to only the first $3 \mathrm{~d}$ after withdrawal of the palatable diet, it seems possible that a heightened metabolic rate, perhaps resulting from hypertrophy of brown adipose tissue (Rothwell \& Stock, 1979 b; Stephens, 1980) may persist beyond the period necessary to reduce fat levels to normal, resulting in excessive leanness.

This work was supported by grants to Professor John Dobbing from the Medical Research Council, and from the National Fund for Research into Crippling Diseases. The author thanks Professor Dobbing, Dr J. L. Smart and Mr P. J. Ormerod for their helpful criticisms of the manuscript, Mrs G. Bourdillon for assistance with the body water assay and $\mathrm{Mr}$ C. J. Whittaker for his advice and help with statistical analyses.

\section{REFERENCES}

Adlard, B. P. F., Dobbing, J. \& Smart, J. L. (1973). Biol. Neonate 23, 95.

Barnes, R. H., Kwong, E., Morrissey, L., Vilhjalmsdottir, L. \& Levitsky, D. A. (1973). J. Nutr. $103,273$. Bernardis, L. L. (1966). Experientia 22, 671.

Bronfenbrenner, U. (1968). In Early Experience and Behavior. [G. Newton and S. Levine, editors]. Springfield, Illinois: Thomas.

Cheng, M., Rozin, P. \& Teitelbaum, P. (197I). J. comp. Physiol Psychol. 76, 206.

Chow, B. F. \& Lee, C. (1964). J. Nutr. 82, Io.

Chow, B. F. \& Stephan, J. K. (197I). Nutr. Rep. int. 4, 245.

Crnic, L. S. (1979). Physiol. Behav. 22, 1025.

Dobbing, J. (I980). In Infant and Child Feeding. [A. M. Thomson, J. Bond, L. Filer, G. A. Leveille and

W. Weil, editors]. New York: Academic Press.

Dobbing, J. \& Sands, J. (1971). Biol. Neonate 19, 363.

Hughes, P. C. R. \& Tanner, J. M. (1970). J. Anat. 106, 349.

Kennedy, G. C. (1957). J. Endocr. 16, 9.

Kennedy, G. C. (1969). Ann. N.Y. Acad. Sci. 157, 1049.

Mundy, L. A. \& Porter, G. (1969). J. Inst. Anim. Techn. 20, 78.

Pace, N. \& Rathbun, E. N. (1945). J. biol. Chem. 158, 685.

Peckham, S. C., Entenman, C. \& Carroll, H. W. (1962). J. Nutr. 77, 187.

Pitts, G. C. \& Bull, L. S. (1977). Am. J. Physiol. 232, R34.

Rolls, B. J. \& Rowe, E. A. (1979). Physiol. Behav. 23, $24 \mathrm{I}$.

Rolls, B. J., Rowe, E. A. \& Turner, R. C. (I980). J. Physiol., Lond. 298, 415.

Rothwell, N. J. \& Stock, M. J. (1978). J. Physiol., Lond. 276, 60P.

Rothwell, N. J. \& Stock, M. J. (1979a). Br. J. Nutr. 41, 625.

Rothwell, N. J. \& Stock, M. J. (1979b). Nature, New Biol. 281, 31.

Rothwell, N. J. \& Stock, M. J. (1980). Proc. Nutr. Soc. 39, 45A.

Sands, J., Dobbing, J. \& Gratrix, C. (1979). Lancet ii, 503.

Schemmel, R., Mickelson, O. \& Tolgay, Z. (I969). Am. J. Physiol. 216, 373. 
Sclafani, A. \& Gorman, A. N. (1977). Physiol. Behav. 18, 1021.

Sclafani, A. \& Springer, D. (1976). Physiol. Behav. I7, 461.

Smart, J. L., Adlard, B. P. F. \& Dobbing, J. (1974). Biol. Neonate 25, 135.

Smart, J. L., Dobbing, J., Adlard, B. P. F., Lynch, A. \& Sands, J. (1973). J. Nutr. 103, I 327.

Stephens, D. N. (1980). Proc. Nutr. Soc. 39, 39 A.

UMRCC (1978). Manchester: SPSS-version 6 on the 7600 at UMRCC p. 145. University of Manchester Regional Computer Centre.

Whatson, T. S. \& Smart, J. L. (1978). Physiol. Behav. 20, 749.

Widdowson, E. M. (1971). Proc. Nutr. Soc. 30, 127.

Widdowson, E. M. \& McCance, R. A. (1960). Proc. Roy. Soc. B 152, 188.

Widdowson, E. M. \& McCance, R. A. (1963). Proc. Roy. Soc. B 158, 329.

Widdowson, E. M. \& McCance, R. A. (1975). Pediat. Res. 9, 154.

Williams, J. P. G., Tanner, J. M. \& Hughes, P. C. R. (1974). Pediat. Res. 8, 149. 